\title{
Steroids Fail to Down-Regulate Respiratory Syncytial Virus-Induced IL-8 Secretion in Infants
}

\author{
LYNETTE H. THOMAS, MIKE SHARLAND, AND JON S. FRIEDLAND \\ Department of Infectious Diseases, Faculty of Medicine, Imperial College of Science, Technology and \\ Medicine, Hammersmith Campus, London, U.K. [L.H.T., J.S.F.]; Pediatric Infectious Diseases Unit, St. \\ George's Hospital Medical School, London, U.K. [M.S.]
}

\begin{abstract}
ABST
In the first year of life, respiratory syncytial virus (RSV) is the
major cause of bronchiolitis and is characterized by extensive
inflammatory cell influx to airways. We investigated whether this
might reflect a failure to down-regulate secretion of the chemo-
kine IL-8, which has been identified as a key chemoattractant
during host defense to RSV. Two milliliters of blood were
obtained from infants, children aged $1-12$ y, and adults. Periph-
eral blood mononuclear cells (PBMC) were isolated and infected
with RSV, and IL-8 secretion was measured by ELISA. The
effect of preincubation of PBMC with either $0.1-10$ MM dexa-
methasone or $1-100$ ng/mL of one of the down-regulatory T
helper 2 cytokines IL-4, IL-10, or IL-13 before RSV infection
was examined. RSV stimulated IL- 8 secretion in a dose-
dependent manner similarly in all age groups. IL- 8 secretion
occurred mainly within 24 h of infection, with maximal concen-
trations of $30,000-46,000$ pg/10 6 cells. IL-4 caused modest
\end{abstract}
inhibition and IL-10 and IL-13 caused no inhibition of IL-8 secretion in all groups. Dexamethasone inhibited IL-8 secretion by $34 \pm 8 \%$ in children and by $41 \pm 3 \%$ in adults but had no effect on infant PBMC. In summary, RSV-induced IL-8 secretion from infant $\mathrm{PBMC}$ is equal to that in children and adults and relatively unaffected by down-regulatory cytokines. However, the inhibitory effects of steroids on IL-8 secretion are absent in infants, which may partly explain why they develop more severe bronchiolitis, and why steroid therapy is unsuccessful in clinical practice. (Pediatr Res 52: 368-372, 2002)

\section{Abbreviations}

RSV, respiratory syncytial virus

PBMC, peripheral blood mononuclear cells

MOI, multiplicity of infection

LPS, lipopolysaccharide
RSV is the major pathogen causing bronchiolitis in infants, resulting in at least 90,000 hospital admissions in the United States annually (1), imposing a major economic burden (2). RSV infection is a risk factor for development of wheezing in childhood (3). Serious RSV infection is uncommon in older children and immunocompetent adults. Host immune responses are important in pathophysiology of infection, as demonstrated by the sometimes fatal exacerbations of bronchiolitis in vaccinated infants (4). Bronchiolitis is partly due to marked inflammatory cell influx to infected airways $(5,6)$, although whether this reflects excessive up-regulation of proinflammatory mediators or failure to down-regulate normal antiviral immune responses is unknown.

Cellular recruitment is dependent on secretion of chemokines, including IL-8. High IL-8 concentrations were present in nasal fluid from RSV-infected children (7) and in plasma from

Received August 10, 2001; accepted February 13, 2002.

Correspondence and reprint requests: Dr. Jon. S. Friedland, Department of Infectious Diseases, Imperial College of Science, Technology and Medicine, Hammersmith Campus, Du Cane Road, London, W12 0NN, U.K.; e-mail: j.friedland@ic.ac.uk

Supported by Action Research, West Sussex, U.K., grant number S/P/2907.

DOI: 10.1203/01.PDR.0000030716.99576.3C infants with severe RSV (8), where concentrations may reflect disease severity (9). RSV-infected macrophages and mononuclear cells secrete high IL-8 concentrations $(10,11)$, although they are not the only cellular sources of IL-8 (12-15).

The relative immaturity of immune responses in infants may contribute to severity of RSV infection. Neonatal lymphocytes, mononuclear cells, and macrophages secrete fewer cytokines in response to a number of stimuli than their adult counterparts (16-18). Reduced IL-4 and IFN- $\gamma$ secretion were reported as markers of severe RSV-bronchiolitis (9), although other data indicate a predominant $\mathrm{T}$ helper 1 cytokine profile in RSV infection (19). There are no data on age-dependent chemokine secretion in RSV infection.

\section{METHODS}

Subject selection. Three groups of subjects were studied: infants $(<1 \mathrm{y})$, children $(1-12 \mathrm{y})$, and adults. The infants and children were undergoing minor, elective surgical procedures and had no evidence of systemic or respiratory illness on questionnaire screening and clinical examination. Two milliliters of blood was venesected before the surgery at the time of routine cannulation. Similar volumes of blood were taken from 
a group of healthy adult volunteers. A detailed history, including enquiry about previous hospital admissions for respiratory illness, family and individual atopic history, breast-feeding, and family smoking history, was obtained for each subject. No subjects were receiving any form of immunosuppressive medication. The study was approved by the St. George's Hospital Research Ethics Committee. Informed consent from those who participated in this study was obtained from parents of infants and children or directly from adult volunteers.

Virus culture and titration. RSV (strain A2) was propagated in HEp-2 cells according to methods described (20) and partially purified by centrifugation at $10,000 \times g$ for $10 \mathrm{~min}$ at $4^{\circ} \mathrm{C}$, to remove cell supernatant. Cells were inoculated with 0.1 MOI RSV and harvested once $>80 \%$ cell detachment was observed. The cell suspension was spun at $13,000 \times g$, and the virus-containing pellet rapidly resuspended in fresh media, aliquoted, snap frozen, and stored at $-80^{\circ} \mathrm{C}$. Virus titer was quantitated using the microplaque immunoperoxidase method (21). Control aliquots generated using uninfected HEp-2 cells had no effect on IL-8 secretion.

Preparation of PBMC. Immediately after collection, whole blood was diluted $1: 1$ with sterile $0.9 \%$ normal saline solution and layered on Ficoll-Paque Plus (Amersham Pharmacia Biotech, Little Chalfont, Buckinghamshire, U.K.) in $1.5-\mathrm{mL} \mathrm{mi-}$ crotubes. PBMC were separated by density gradient centrifugation at $500 \times g$, washed three times in sterile Hanks' balanced salt solution, and then resuspended in serum-free Dulbecco's modified Eagle's medium (Invitrogen, Carlsbad, CA, U.S.A.), supplemented with $2 \mathrm{mM}$ glutamine and 10 $\mu \mathrm{g} / \mathrm{mL}$ ampicillin. The PBMC were plated at $1.5 \times 10^{5}$ cells per well in $0.5 \mathrm{~mL}$ media in 24-well plates and maintained in $5 \% \mathrm{CO}_{2}$ at $37^{\circ} \mathrm{C}$. The total number of PBMC obtained from the $2 \mathrm{~mL}$ blood from infants was approximately $4-8 \times 10^{6}$ cells.

PBMC stimulation. PBMC were infected with RSV at a MOI of $0.1,0.3$, or 1 and cultured for either 24 or $48 \mathrm{~h}$. Cells cultured in serum-free medium alone were the negative control. Time points were selected on the basis of preliminary studies in PBMC and similar work from this and other laboratories investigating respiratory epithelial cells $(22,23)$. In specific experiments investigating the effects of steroids, PBMC were preincubated for $1 \mathrm{~h}$ with and then cultured in the presence of serial dilutions of dexamethasone $(0.1,1$, or 10 $\mu \mathrm{M})$ and then infected with RSV at a MOI of 0.3. To investigate the effects of IL-4, IL-10, or IL-13 (Peprotech. London, U.K.), PBMC were pretreated for $1 \mathrm{~h}$ with either 1,10 , or 100 $\mathrm{ng} / \mathrm{mL}$ of each cytokine before RSV infection. Each T helper 2 cytokine remained in the tissue culture medium for the duration of the experiment. After the culture period, supernatants were harvested and stored at $-80^{\circ} \mathrm{C}$ for IL- 8 analysis. These inhibitors did not cause significant cell death over the 24-h study period (data not shown).

IL-8 ELISA and analysis of data. IL-8 concentrations in supernatants were measured by specific ELISA, using matched-paired antibodies and recombinant standards from $\mathrm{R}$ \& D Systems Europe (Oxford, U.K.). The lower limit of sensitivity of the assay was $16-31 \mathrm{pg} / \mathrm{mL}$. IL- 8 concentrations within samples are expressed as picograms per $10^{6}$ cells, and stimulated levels of IL-8 were corrected for unchallenged release levels. The mean \pm SEM was calculated for each data point, and data within groups were compared using Wilcoxon matched pair tests. Comparisons between age groups were performed using Mann-Whitney $U$ tests.

\section{RESULTS}

Subject characteristics. We studied 12 infants (mean age 19 $\pm 4 \mathrm{wk}), 16$ children $(60 \pm 10 \mathrm{mo})$, and 12 adults $(35 \pm 3 \mathrm{y})$, none of whom had a current respiratory illness (Table 1). Two infants and five children had previously been admitted to hospital with respiratory infections or asthma, none of which none were due to RSV. In the United Kingdom, it would be expected that by 24 mo of age, over $90 \%$ individuals will have a detectable immunologic response to RSV. Therefore, it is likely that virtually all children and adults had been exposed to RSV, although this was not tested. No adult had been admitted for a chest infection within $20 \mathrm{y}$. There was no unexpectedly high incidence of drug allergies or atopy (including asthma, eczema, and hay fever) in subjects or their families. Parental smoking is a risk factor for respiratory illness (24) and about $50 \%$ infants and children came from households with one or more smokers. Breast-feeding is protective against respiratory tract illnesses in early life (25), and both infants' and children's groups contained approximately equal proportions of breastfed subjects.

Table 1. Clinical characteristics of study groups

\begin{tabular}{lccc}
\hline & Infants & $1-12 \mathrm{y}$ & Adults \\
\hline No. subjects & 12 & 16 & 12 \\
Age range & $19 \pm 4 \mathrm{wk}$ & $60 \pm 10 \mathrm{mo}$ & $35 \pm 3 \mathrm{y}$ \\
M:F ratio & $10: 2$ & $15: 1$ & $8: 4$ \\
No. that were previous inpatients & 2 & 5 & $0^{*}$ \\
$\quad$ for respiratory illness & 6 & 10 & $\mathrm{ND}$ \\
No. breast fed & 0 & 7 & 8 \\
No. atopic patients & 6 & $12 \dagger$ & $5 \dagger$ \\
No. with family history of atopy & 5 & 8 & 4 \\
No. with smokers in household & & & \\
\hline
\end{tabular}

* Information unavailable for early childhood.

$\dagger$ In each case, one value is missing, as information unavailable. $\mathrm{ND}$, no data.
(A)

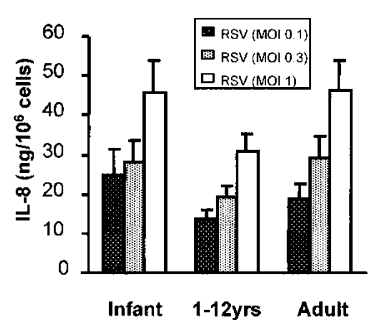

(B)

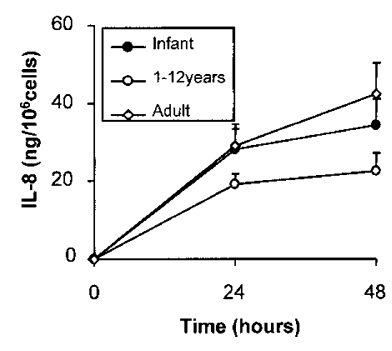

Figure 1. IL-8 secretion from RSV-infected PBMC from infants $(n=12)$, children $(n=16)$, and adults $(n=12)$. ( $A$ ) The effect of increasing infectious dose. PBMC were infected with RSV at MOI of $0.1,0.3$, or 1 . Supernatants were then harvested after $24 \mathrm{~h}$ and IL- 8 concentrations measured by ELISA. $(B)$ Kinetics of IL-8 secretion. PBMC were infected with RSV $(\mathrm{MOI}=0.3)$ and cultured for up to $48 \mathrm{~h}$. IL-8 concentrations were then measured in culture supernatants. All data are given as mean $\pm \mathrm{SEM}$, in picograms per $10^{6}$ cells, for each age group. $p=\mathrm{NS}$ for all comparisons between age groups by unpaired Mann-Whitney tests. 
$\boldsymbol{R S V}$-induced IL-8 secretion. Infection with RSV induced IL- 8 secretion from PBMC at $24 \mathrm{~h}$ of culture, dependent on the MOI (Fig. 1A). IL-8 concentrations secreted by infant RSVinfected PBMC were 24,720 $\pm 6520,28,280 \pm 5180$, and $45,710 \pm 8010 \mathrm{pg} / 10^{6}$ cells in response to $0.1,0.3$, and $1 \mathrm{MOI}$ of RSV, respectively. At all ages, the increase in IL-8 concentrations after stimulation by RSV at an MOI of 1.0 compared with an MOI of either 0.1 or 0.3 were significant $(p<0.001)$. Comparing IL-8 secretion after exposure to RSV at an MOI of 0.1 with RSV at an MOI of 0.3 , the increase in IL- 8 secretion was significant in both children and adults $(p<0.01)$ but not in the infant group, possibly due to the number of patients studied. There were no significant differences in RSV-induced IL- 8 secretion between the three age groups. Most IL- 8 secretion occurred within $24 \mathrm{~h}$ and did not increase greatly between 24 and 48 h (Fig. 1B). IL-8 secretion did not relate to clinical characteristics and was unaffected by household smokers or breast-feeding.

Effect of dexamethasone on IL-8 secretion. Preincubation of PBMC with dexamethasone caused dose-dependent, partial inhibition of RSV-induced IL-8 secretion in adults and older children. Maximal reduction of IL-8 secretion was $34 \pm 8 \%$ in children and $41 \pm 13 \%$ in adults $(p<0.05$ compared with untreated cells by paired Wilcoxon test). In contrast, dexamethasone did not alter IL-8 secretion from infant PBMC (Fig. 2), which were $28,280 \pm 5180 \mathrm{pg} / 10^{6}$ from untreated cells, and $27,270 \pm 9500 \mathrm{pg} / 10^{6}$ from cells pretreated with $10 \mu \mathrm{M}$ dexamethasone $(p=\mathrm{NS})$. In contrast to the differences between the three groups, within each group there was no discernible trend in terms of IL- 8 secretion in relation to age. For example, in the infant group, only two patients showed suppression of IL-8 in response to dexamethasone, of whom one was aged $8 \mathrm{wk}$ and one $18 \mathrm{wk}$ (mean age group $19 \pm 4 \mathrm{wk}$ ).

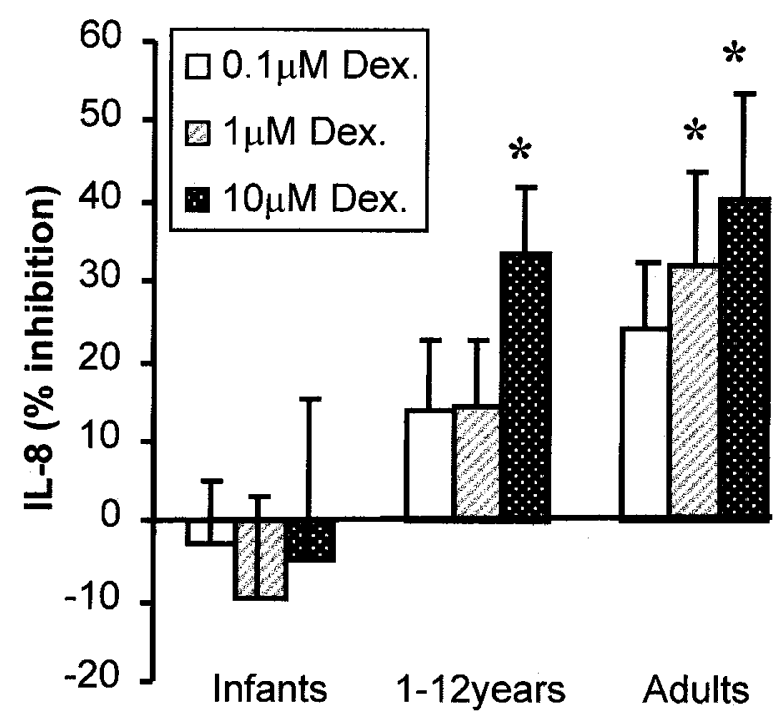

Figure 2. Effect of increasing doses of dexamethasone on RSV-induced IL-8 secretion. PBMC from infants, 1-12 y olds, or adults were preincubated with increasing concentrations $(0.1,1,10 \mu \mathrm{M})$ of dexamethasone for $1 \mathrm{~h}$, before infection with RSV (MOI $=0.3)$. Supernatants were harvested after $24 \mathrm{~h}$ culture, and IL-8 measured by ELISA. Data are expressed as percentage inhibition, and given as mean \pm SEM for each age group. ${ }^{*} p<0.05$ compared with untreated cells infected with RSV (paired Wilcoxon test).
In contrast, dexamethasone did not at any age decrease RANTES secretion, which we found was induced by RSV in a similar dose- and time-dependent manner to IL-8, although at a lesser magnitude.

Effect of IL-4, IL-10, and IL-13 on RSV-induced IL-8 secretion. Finally, the effects of IL-4, IL-10, and IL-13 on RSV-induced IL-8 secretion were examined. Table 2 shows that only $100 \mathrm{ng} / \mathrm{mL} \mathrm{IL-4} \mathrm{exerted} \mathrm{any} \mathrm{inhibitory} \mathrm{action,} \mathrm{de-}$ creasing IL-8 secretion by $31 \pm 6 \%$ in infants, $36 \pm 7 \%$ in children, and $34 \pm 14 \%$ in adults $(p<0.05$ compared with untreated). IL-10 and IL-13 had no significant effects on RSV-induced IL-8 secretion from PBMC at any concentration used in this study. There were also no differences observed between the responses of RSV-infected PBMC to IL-4, IL-10, or IL-13 in the different age groups.

\section{DISCUSSION}

This study demonstrates that the magnitude and kinetics of IL-8 secretion from RSV-infected PBMC are similar in infants, adults, and children, even with increasing infectious load (MOI). Although the blood volumes available were insufficient to perform parallel studies using LPS, these data are consistent with earlier work showing that LPS-stimulated cord blood mononuclear cells secrete as much IL-8 as maternal monocytes (26). In contrast, neonatal monocyte-derived macrophages and lymphocytes secrete less IFN- $\gamma$ than adult cells (16) and PBMC secrete less IL-3, IL-15, and granulocyte-macrophage colony stimulating factor (27). The data concerning agedependent responses to RSV are inconsistent with both increased and reduced cell-mediated immunity reported $(28,29)$. Such differences may be stimulus and mediator specific. RSVinfected neonatal macrophages secrete the proinflammatory cytokines tumor necrosis factor- $\alpha$ and IL- 6 to a normal concentration (30). Together with our findings, the data indicate that although neonatal cells display immaturity in some immune responses, they have a mature proinflammatory response, including IL-8 secretion.

IL-8 secretion occurred within $24 \mathrm{~h}$ of RSV infection, suggesting that viral replication is not required; RSV is known to infect but not multiply within mononuclear cells (31). We did not determine the source of IL- 8 , but it is likely to be lymphocyte and monocyte derived. Ex vivo infection of PBMC by RSV is a useful, relevant model for investigating immune responses inasmuch as these cells are recruited to airways early in infection. Furthermore, circulating mononuclear cells from infants with RSV express viral antigen (31), and measuring RSV RNA in whole blood by reverse transcriptase PCR during clinical bronchiolitis has been used to confirm systemic spread of virus (32). Infant monocytic cells may even be more prone than adult cells to RSV infection (33).

The most striking observation was that in infants but not in children or adults, dexamethasone did not to suppress PBMC IL-8 secretion. However, within each group, there were no clear age-dependent trends in IL-8 secretion. Potentially, this may result in prolonged, proinflammatory cell influx to sites of infection. The observation is consistent with the lack of benefit, in terms of disease resolution or severity, of administration of 
Table 2. IL-8 concentrations (ng/10 cells) after RSV infection of PBMC: effect of pretreatment with IL-4, IL-10, or IL-13

\begin{tabular}{|c|c|c|c|c|c|c|c|c|c|c|c|c|c|}
\hline \multirow{2}{*}{$\begin{array}{c}\text { Pretreatment } \\
\text { concentration }(\mathrm{ng} / \mathrm{mL})\end{array}$} & \multirow{2}{*}{$\begin{array}{c}\text { None } \\
0\end{array}$} & \multicolumn{4}{|c|}{ IL-4 } & \multicolumn{4}{|c|}{ IL-10 } & \multicolumn{4}{|c|}{ IL-13 } \\
\hline & & 1 & 10 & 100 & $p^{*}$ & 1 & 10 & 100 & $p^{\dagger}$ & 1 & 10 & 100 & $p \ddagger$ \\
\hline Infant & $38 \pm 9$ & $40 \pm 10$ & $31 \pm 9$ & $28 \pm 8$ & $<0.05$ & $43 \pm 12$ & $42 \pm 11$ & $38 \pm 9$ & NS & $41 \pm 9$ & $35 \pm 10$ & $33 \pm 9$ & NS \\
\hline Adult & $40 \pm 8$ & $36 \pm 8$ & $29 \pm 5$ & $26 \pm 4$ & $<0.05$ & $38 \pm 7$ & $37 \pm 7$ & $36 \pm 7$ & NS & $32 \pm 5$ & $34 \pm 6$ & $40 \pm 7$ & NS \\
\hline
\end{tabular}

* Comparison between IL-8 secretion for RSV alone and maximal concentration (100 ng/mL) of IL-4 (paired Wilcoxon test).

$\dagger$ Comparison by Wilcoxon tests of IL-8 secretion from untreated PBMC vs PBMC pretreated with IL-10 (all concentrations).

$\$$ Comparison by Wilcoxon tests of IL-8 secretion from untreated PBMC vs PBMC pretreated with IL-13 (all concentrations).

dexamethasone in RSV infection $(34,35)$. The mechanism underlying this observation is the subject of ongoing research. However, this effect appears specific and, in preliminary studies, dexamethasone reduced LPS-induced IL- 8 secretion at all ages, which is consistent with data from Taniguchi et al. (26). In addition, the effect seems chemokine-specific in that this steroid had no effect on RANTES secretion.

IL-4, IL-10, and IL-13, T helper 2 cytokines, which often down-regulate monocyte chemokine secretion $(36,37)$, did not effectively block IL-8 secretion from RSV-infected PBMC, although high IL-4 concentrations partially inhibited secretion in all age groups. The specific response to IL-4 may reflect differences in their mechanisms of action; for example, IL-10 blocks LPS-induced nuclear factor- $\kappa \mathrm{B}$ activation in monocytes, whereas IL-4 decreases stability of transcribed mRNA (37). In addition, T cells possess functional IL-4 but not IL-13 receptors. The fact that IL-4 had the most effect (even though this was a modest one) is consistent both with experimental observations in murine models in which a critical role for IL-4 in development of airway hyperresponsiveness was found, with overexpression of IL-4 delaying clearance of RSV (38, 39). The lack of effect of IL-10 was somewhat unexpected inasmuch as endogenous IL-10 increases during clinical RSV infection (40) and has been associated with subsequent development of recurrent wheezing (41). However, our data are consistent with the fact that ex vivo IL-10 secretion does not relate to severity of RSV as reflected by required duration of mechanical ventilation (42). Although recent murine studies have once again emphasized a role for IL-13 in airways hyperreactivity (43), our data indicate that this is not mediated by effects on acute IL-8 (or RANTES) secretion in humans.

In summary, infant PBMC display a normal IL-8 activation in response to RSV, compared with children and adults, that is not easily inhibited by down-regulatory cytokines. However, infant PBMC do not respond to down-regulation by dexamethasone. The efficient secretion of "adult" concentrations of IL-8 in response to $\mathrm{RSV}$, coupled with a relative resistance to down-regulatory stimuli, coupled with the immature immune system, may contribute to exaggerated and prolonged inflammatory response in RSV-infected infants. These data may also explain part of the mechanism underlying the lack of benefit from steroids in treatment of RSV bronchiolitis. Further studies in RSV-infected infants are required to dissect out the mechanisms and further define the importance of the current observations.

Acknowledgments. The authors thank the pediatric surgical and nursing staff at St. George's Hospital, particularly Dr.
Hulse, Mr. Holmes, and Dr. Burton, for their invaluable help with collection of blood samples.

\section{REFERENCES}

1. Breese-Hall C 1994 Prospects for a respiratory syncytial virus vaccine. Science 265:1393-1394

2. Howard TS, Hoffman LH, Stang PE, Simoes EA 2000 Respiratory syncytial virus pneumonia in the hospital setting: length of stay, charges, and mortality. J Pediatr 137:227-232

3. Stein RT, Sherill D, Morgan WJ, Holberg CJ, Halonen M, Taussig LM, Wright AL, Martinez FD 1999 Respiratory syncytial virus in early life and risk of wheeze and allergy by age 13 years. Lancet 354:541-545

4. Kim HW, Canchola JG, Brandt CD, Pyles G, Chanock RM, Jensen K, Parrott RH 1969 Respiratory syncytial virus disease in infants despite prior administration of an antigenic inactivated vaccine. Am J Epidemiol 89:422-433

5. Aherne W, Bird T, Court SDM, Gardner PS, McQuillin J 1970 Pathological changes in virus infections of the lower respiratory tract in children. J Clin Pathol 23:7-18

6. Everard ML, Swarbrick A, Wrightham M, McIntyre J, Dunkley C, James PD, Sewell HF 1994 Analysis of cells obtained by bronchial lavage of infants with respiratory syncitial virus infection. Arch Dis Child 71:428-432

7. Noah TL, Henderson FW, Wortman IA, Devlin RB, Handy J, Koren HS, Becker S 1995 Nasal cytokine production in viral acute upper respiratory infection of childhood. J Infect Dis 171:584-592

8. Biswas S, Friedland JS, Remick DG, Davies EG, Sharland M 1995 Elevated plasma interleukin-8 in respiratory syncytial virus bronchiolitis. Pediatr Infect Dis J 14:919

9. Bont L, Heijnen CJ, Kavelaars A, van Aalderen WM, Brus F, Draaisma JMT, Geelen SM, vanVught HJ, Kimpen JL 1999 Peripheral blood cytokine responses and disease severity in respiratoy syncytial virus bronchiolitis. Eur Resp J 14:144-149

10. Becker S, Quay J, Soukup J 1991 Cytokine (tumour necrosis factor, IL-6 and IL-8) production by respiratory syncytial virus-infected human alveolar macrophages. J Immunol 147:4307-4312

11. Arnold R, König B, Gallati H, Werchau H, König W 1995 Cytokine (IL-8, IL-6, TNF- $\alpha$ ) and soluble TNF receptor-I release from human peripheral blood mononuclear cells after respiratory syncytial virus infection. Immunology 85:364-372

12. Fiedler MA, Wernke-Dollries K, Stark JM 1996 Mechanism of RSV-induced IL-8 gene expression in A549 cells before viral replication. Am J Physiol 271:L963-L971

13. Jamaluddin M, Garofalo R, Ogra PL, Brasier AR 1996 Inducible translational regulation of the NF-IL6 transcription factor by respiratory syncytial virus infection in pulmonary epithelial cells. J Virol 70:1554-1563

14. Olszewska-Pazdrak B, Casola A, Saito T, Alam R, Crowe SE, Mei F, Ogra PL, Garafalo RP 1998 Cell-specific expression of RANTES, MCP-1, and MIP-1alpha by lower airway epithelial cells and eosinophils infected with respiratory syncytial virus. J Virol 72:4756-4764

15. Mastronarde JG, Monick MM, Mukaida N, Matsushima K, Hunninghake GW 1998 Activator protein-1 is the preferred transcription factor for cooperative interaction with nuclear factor kappaB in respiratory syncytial virus-induced interleukin- 8 gene expression in airway epithelium. J Infect Dis 177:1275-1281

16. Scott ME, Kubin M, Kohl S 1997 High level interleukin-12 production, but diminished interferon- $\gamma$ production, by cord blood mononuclear cells. Pediatr Res 41:547553

17. Matsuda K, Tsutumi H, Sone S, Yoto Y, Oya K, Okamoto Y, Ogra PL, Chiba S 1996 Characteristics of IL- 6 and TNF- $\alpha$ production by respiratory syncytial virus-infected macrophages in the neonate. J Med Virol 48:199-203

18. Blanco-Quiros A, Gonzalez H, Arranz E, Lapena S 1999 Decreased interleukin-12 levels in umbilical cord blood in children who developed acute bronchiolitis. Pediatr Pulmonol 28:175-180

19. Anderson LJ, Tsou C, Potter C, Keyserling HL, Smith TF, Ananaba G, Bangham CR 1994 Cytokine response to respiratory syncytial virus stimulation of human peripheral blood mononuclear cells. J Infect Dis 170:1201-1208

20. Alwan WH, Record FM, Openshaw PJ 1993 Phenotypic and functional characterization of $\mathrm{T}$ cell lines specific for individual respiratory syncytial virus proteins. J Immunol 150:5211-5218

21. Cannon MJ 1987 Microplaque immunoperoxidase detection of infectious respiratory syncytial virus in the lungs of infected mice. J Virol Methods 16:293-301

22. Thomas LH, Wickremasinghe M, Sharland M, Friedland JS 2000 Synergistic upregulation of IL-8 secretion from pulmonary epithelial cells by direct and monocytedependent effects of respiratory syncytial virus infection. J Virol 74:8425-8431 
23. Garofalo RM, Sabry M, Jamaluddin M, Yu RK, Casola A, Ogra PL, Brasier AR 1996 Transcriptional activation of the interleukin- 8 gene by respiratory syncytial virus infection in alveolar epithelial cells: nuclear translocation of the RelA transcription factor as a mechanism producing airway mucosal inflammation. J Virol 70:87738781

24. Strachan DP, Cook DG 1997 Health effects of passive smoking I. Parental smoking and lower respiratory illness in infancy and early childhood. Thorax 52:905-914

25. Wright AL, Holberg CJ, Martinez FD, Morgan WJ, Taussig LM 1989 Breast feeding and lower respiratory tract illness in the first year of life. BMJ 14:946-949

26. Taniguchi T, Matsuzaki N, Shimoya K, Neki R, Okada T, Kitajima H, Saji F, Tanizawa O 1993 Fetal mononuclear cells show a comparable capacity with maternal mononuclear cells to produce IL-8 in response to lipopolysaccharide in chorioaminionitis. J Reprod Immunol 23:1-12

27. Qian JX, Lee SM, Suen Y, Knoppel E, van de Ven C, Cairo MS 1997 Decreased interleukin-15 from activated cord versus adult peripheral blood mononuclear cells and the effect of interleukin-15 in upregulating antitumor immune activity and cytokine production in cord blood. Blood 90:3106-3117

28. Scott R, Kaul A, Scott M, Chiba Y, Ogra PL 1978 Development of in vitro correlates of cell-mediated immunity to respiratory syncytial virus infection in humans. J Infect Dis 137:810-817

29. Chiba Y, Higashidate Y, Suga K, Honjo K, Tsutumi H, Ogra PL 1989 Development of cell-mediated cytotoxic immunity to respiratory syncytial virus in human infants following naturally-acquired infection. J Med Virol 28:133-139

30. Tsutsumi H, Matsuda K, Sone S, Takeuchi R, Chiba S 1996 Respiratory syncytial virus-induced cytokine production by neonatal macrophages. Clin Exp Immunol 106:442-446

31. Domurat F, Roberts NJ, Walsh EE, Dagan R 1985 Respiratory syncytial virus infection of human mononuclear leukocytes in vitro and in vivo. J Infect Dis 152:895-902

32. O'Donnell DR, McGarvey MJ, Tully JM, Balfour-Lynn IM, Openshaw PJ 1998 Respiratory syncytial virus RNA in cells from the peripheral blood during acute infection. J Pediatr 133:272-274

33. Midulla F, Huang YT, Gilbert IA, Cirino NM, McFadden ER, Panuska JR 1989 Respiratory syncytial virus infection of human cord and adult blood monocytes and alveolar macrophages. Am Rev Respir Dis 140:771-777
34. De Boeck K, Van der Aa N, Van Lierde S, Corbeel L, Eeckels R 1997 Respiratory syncytial virus bronchiolitis: a double blind dexamethasone efficacy study. J Pediatr 131:919-921

35. Roosevelt G, Sheehan K, Grupp-Phelan J, Tanz RR, Listernick R 1996 Dexamethasone in bronchiolitis: a randomised controlled trial. Lancet 348:292-295

36. de Waal Malefyt R, Figdor CG, Huijbens R, Mohan-Peterson S, Bennett B, Culpepper J, Dang W, Zurawski G, de Vries JE 1993 Effects of IL-13 on phenotype, cytokine production, and cytotoxic function of monocytes. Comparison with IL-4 and modulation by interferon-gamma or IL-10. J Immunol 151:6370-6381

37. Wang P, Wu P, Seigel MI, Egan RW, Billah MM 1995 Interleukin (IL)-10 inhibits nuclear factor $\kappa \mathrm{B}(\mathrm{NF} \kappa \mathrm{B})$ activation in human monocytes: IL-10 and IL-4 suppress cytokine synthesis by different mechanisms. J Biol Chem 270:9558-9563

38. Fischer JE, Johnson JE, Kuli-Zade RK, Johnson TR, Aung S, Parker RA, Graham BS 1997 Overexpression of interleukin-4 delays virus clearance in mice infected with respiratory sycytial virus. J Virol 71:8672-8677

39. Schwarze J, Cieslewicz G, Joetham A, Ikemura T, Makela MJ, Dakhama A, Shultz LD, Lamers MC, Gelfand EW 2000 Critical roles for interleukin-4 and interleukin-5 during respiratory sycytial virus infection in the development of airway hyperresponsiveness after airway sensitization. Am J Respir Crit Care Med 162:380-386

40. Sheeran P, Jafri H, Carubelli C, Saavedra J, Johnson C, Krisher K, Sanchez PJ, Ramilo O 1999 Elevated cytokine concentrations in the nasopharyngeal and tracheal secretions of children with respiratory syncytial virus disease. Pediatr Infect Dis J 18:115-122

41. Bont L, Heijnen CJ, Kavelaars A, van Aalderen WM, Brus F, Draaisma JT, Geelen SM, Kimpen JL 2000 Monocyte IL-10 production during respiratory syncytial virus bronchiolitis is associated with recurrent wheezing in a one-year follow-up study. Am J Respir Crit Care Med 161:1518-1523

42. Bont L, Kavelaars A, Heijnen CJ, van Vught AJ, Kimpen JL 2000 Monocyte interleukin-12 production is inversely related to duration of respiratory failure in respiratory syncytial virus bronchiolitis. J Infect Dis 181:1772-1775

43. Lukacs NW, Tekkanat KK, Berlin A, Hogaboam CM, Miller A, Evanhoff H, Lincoln P, Maassab H 2001 Respiratory syncytial virus predisposes mice to augmented allergic airway responses via IL-13-mediated mechanisms. J Immunol 167:10601065 